This is an electronic reprint of the original article. This reprint may differ from the original in pagination and typographic detail.

Please cite the original version: S. Luojus, P. Tossavainen (2019) New Insights in Higher Education: Leading Service Design, INTED2019 Proceedings, pp. 2972-2980.

doi: 10.21125/inted.2019.0784 


\title{
NEW INSIGHTS IN HIGHER EDUCATION: LEADING SERVICE DESIGN
}

\author{
Satu Luojus ${ }^{1}$, Päivi J. Tossavainen ${ }^{2}$ * \\ ${ }^{1}$ Laurea University of Applied Sciences (FINLAND) \\ ${ }^{2}$ Laurea University of Applied Sciences (FINLAND)
}

\begin{abstract}
Organisations are adjusting into the service economy. Hence, new competences are needed. This paper discusses competence development for service economy focusing on service business and the emerging discipline of service design. The paper investigates the new insights needed in management competencies. The paper proposes service design methodology as part of the manager education. The main argument of the paper is that service design leadership needs to be anchored to one of the conventional theoretical disciplines in order to enhance the academic reliability of it and to have impact in business management. We suggest that the service design is anchored to service marketing. This paper advances new insights of service approach and leading service design. Preliminary findings of the ongoing study are presented. The most essential finding is that the management competence develops during higher education slowly and competence requirements are fulfilled only when the master thesis project is accomplished.
\end{abstract}

Keywords: higher education; service design; management competences, case study

\section{INTRODUCTION}

Modern societies are moving towards service society. Organizations are adjusting in the service economy. This means the increase of service business and need to develop both the service business and novel services. Hence, new competences are needed. This transformation requires new capabilities in working life and thus, service design has been suggested as conclusive capability to cope within the service society [1]. The main argument of the paper is that service design leadership needs to be anchored to one of the conventional theoretical disciplines in order to enhance the academic reliability of it, and to have impact in business management. We suggest that the service design is anchored to service marketing as a theoretical proposal. This paper advances identified new competences of service approach and leading service design.

The modern higher education aims to educate future multicompetent professionals. In higher education in Europe, the European Qualifications Framework (EQF) provides the framework for competence development offered thru the degree programs. In this paper, we focus only on master's level education (EQF7) and discuss managerial competence development with the emerging discipline of service design.

The EQF provides the framework for competence development offered in the degree programs thru eight reference levels and describes the learning outcomes of those levels. Moreover, according to the Finnish National Qualifications Framework (NQF) the aim of Master's programmes in universities of applied sciences is that a person who has completed the degree has both in-depth knowledge and the theoretical skills required for development of the workplace with demanding expert and managerial duties. Both frameworks, EQF7 and NQF7 highlight the importance of managerial competence.

The aim of the studied degree program is not to educate service designers, but future business professionals for managerial positions. The purpose of the program is to educate leaders for organizations adopting service-driven worldview in business. All this, requires developing the content 
and methods of master's degree education also in relation to service design. This paper explores opportunities the HEls have in shaping their management education programs and curricula based on the latest changes in business disciplines. The purpose of this paper is to elaborate how these competences are learned during the Master's degree studies at Laurea University of Applied Sciences. The program aims to educate leaders for organisations adopting service-driven worldview in business.

\section{LITERATURE POSITS SERVICE-DRIVEN ECONOMY}

The literature posits a positive relationship between business opportunities and service development. However, empirical evidence is inconclusive with the management and leadership of the service development and design.

Services have become the most important economic power in the world. Yet, mostly developed within the mainstream theoretical underpinnings of industrial logics Currently, the dominant logic in management education and managing business is the industrial logic, which - in short - means the exchange of (mass) manufactured products (goods) thru tangible resources, and with embedded value (i.e. price), and transactions. Business management is heavily dependent of relying on industrial logic that focuses on the productivity and the profitability of the firm; so is the management education. Service logics, however, focuses on service provision [2]; on resource integration [3], the creation of value or co-creation of value [4], [5].

This mind-set is one of the most challenging issue in the theoretical shift that is the basis of the new management competences: the understanding the difference between industrial logic and service logics. Modifying the tradition of higher education is not an easy task, but the paper proposes that new insights in management competences are justified.

The main change from twentieth -century to the $21^{\text {st }}$ century can be described as growing complexity rooting from the social aspects, innovation, and service [6]. In business research, this has led to the theoretical paradigm shift from industrial- or production-driven worldview to service-driven perspective. The recent academic discussion of the theoretical fundamentals and evolution of service research; service marketing and management, service-dominant logic, customer-dominant logic, service innovation, and service systems (see for example, [7], [8], [9], [10], [11]) clearly illustrate the widespread interest. And it is not that new idea: Grönroos [2] reminds that the development of serviceoriented concepts and models had started already in the 1970s, and related research has since been active especially in Europe. This viewpoint requires a holistic change in managing a business enterprise and novel means to develop the business. New competencies are required in understanding holistically the changes based on the changes in worldview and also the means of achieving the changes.

Thus, service-driven perspective is a chosen lens to look at the world and business. Vargo and Lusch [12] categorise this view of marketing as the twenty-first century service-centred model of exchange in contrast to the viewpoint of goods-centred model of exchange. Three major changes has been noted: the business strategy is no longer based on the firm's capabilities, i.e. firm-centric view but based on the customer; the customer-centric view. The service thinking means collaborating with and learning from customers, and being adaptive to their individual and dynamic needs [11]. Secondly, the new role of the customer as active co-creator and co-designer of a service is accepted [12], [13], and [4]. Thirdly, the concept of value, which in industrial logic is the (monetary) mean of exchange, which is based on costs (value-in-exchange). After exchange, the value destruction begins. For the customer, the cost perspective is somewhat irrelevant while s/he is looking for the value-in-use of the service to her/his life [14].

Modern societies are moving towards service economy. This means the increase of service business and need to develop both the service business and individual services. In particular, service development competences are distinctive competences, which rely on service theories (knowledge) and their implications in practice. Thus, Ojasalo and Ojasalo [15] suggests that the business practitioners need competencies that combine both business management and design competences. Service design approach has been suggested as conclusive capability to cope within the service society [1]. The role of HEls is to enable graduates from various disciplines to become T-shaped professionals or adaptive innovators [17], [16]. Moreover, authors [18] suggested that higher education institutes should educate new professionals with service-oriented mind-sets. One issue that has received little attention in management literature is that of the influence of service-driven perspective 
has into management competences and managing business. The modification of the management education hardly discusses the influence of it in competence development acquired thru the higher education. Thus, this paper discusses the role of an emerging discipline of service design approach as a part of the new management competency.

Recently, the service innovation and design education was investigated [19]. The study revealed that the education of service innovation and design is still relatively unstructured, unstandardized and indefinable: there is some degree programs available, but is hat not received mainstream discipline status at university level. In general, it seems to be that service design education is short-term trainings or individual courses embedded into programs. Thus, the holistic view of the benefits of these competences and the business benefits may remain inadequate [19], [20].

The purpose of the paper is to influence the development of management education to include new insights into it. Modernization of management education requires innovative approaches. Service design approach and service innovation are seen as vehicles for improved business. However, capabilities related to service development and service innovation are not necessarily evolved in firms.

Service approach calls for novel methods and tools to operationalise the theoretical constructs in practise. For example, how value is co-created with service provider (network), customers and users requires mind-set change and new ways of developing services. Service design leadership may be in key role with successful service business. Thus, managing and leading service design for the benefit of business is a future management competence.

\subsection{Service design approach}

Service design practices also challenges the traditional organizational processes and can be a transformative power in organizations [21].

The service design is an interdisciplinary academic field that originated from design research and adapted methods from other academic disciplines. Service design integrates methods and tools from several disciplines, such as interaction and product design, engineering, anthropology, psychology as well as various business disciplines and service marketing and management (e.g. [6], [22], [23], [24] [25]). Since service design is an emerging and multi-disciplinary field of study, several of its basic concepts are still fairly superficially defined and the theoretical framework is fragmented. The objective of this paradigm shift taking currently place is to integrate business and design fields.

Service design aims at creating services that are both useful, usable and desirable from the user perspective, and simultaneously efficient, effective and different from the provider perspective. The service design approach provides process models and a practical set of methods and tools to involve with users in the service innovation process, explore users' world, and, eventually, design for improved user experiences. Also, the service design methods bring users and user experience into the focus of service development. The participatory and collaborative nature of service design approach is new to business management competences.

Stickdorn and Schneider [26] discuss the five core principles of service design thinking: it is usercantered; co-creative with customers and other stakeholders and within the multidisciplinary team, the work is sequenced in processes; evidenced with visualizations, prototypes, metrics, and holistic throughout the whole service. As such, the service design processes are iterative. There are several service design process models or frameworks (e.g. [27], [26], [28]) consisting of three or even up to seven phases, but fundamentally all service design processes share the same logic and mind-set. Service design processes are usually presented to have a clear and chronological structure, but in reality the service design processes are nonlinear and iterative by nature. [26], [29]

The service design approach favours innovative research methods because typically a rich research data is gathered by these methods in empathic and human-centric manner to provide stimuli that allow ideas and insights to be created and opportunities to share them [30]. These methods are meant to support both the designers and the users in their creativity and interpretations during the service design process. Yet, scalability of collecting and analysing rich data raises questions of practicalities, sustainability, and viabilities. Furthermore, the justification for this needs to be grounded in business strategies and development principles. 


\subsection{Intertwined nature of theory and practise}

In higher education, especially in master's level education the knowledge of the theoretical underpinnings and the operationalisation of theories are learned. The degree programs focus on explaining the intertwined nature of theory and practise. This lays the foundation for new competences.

As service design has become a widespread phenomenon in business world, we took a look for its origin. The service design techniques and tools originate from Design disciplines but can also be linked to the service -driven approach. Current literature rarely addresses this intertwinement while the research is separate either on marketing discipline or design discipline. Therefore, our attempt is to weave these approaches closer together. Hence, based on the literature, we suggest that the new management competences delineated first, service logics as theoretical stronghold and second, linked with service design competences as execution skills. The competencies useful at the service design field are identified in the map of design for services [6], which is the first attempt to depict design for service and categorize methods into for main areas: design for service policies, service experiences, service systems development, and service transformation. However, this map is too abstract to identify the new management competences required. Tossavainen [31] defined service capabilities as learned and practiced know-how and competences in the field of service know-how. Assumed is that the service design methods and tools can improve the realization of service theories in everyday business and hence improve the bottom line of the business enterprise. She crafted the framework of service capabilities as the function of service theories adoption and the use of service driven methods that include a combination of service development and service design methods, techniques, and tools.

The main argument of the paper is that service logics and service design intertwine in the new management competences. Thus, service design needs to be anchored to one of the conventional theoretical business disciplines in order to enhance the academic reliability of it and to have impact in business management.

To conclude the literature review, we found that less is considered how service business, service innovation and service design are related into management competences. Service development, and the aimed service innovations takes place in multidisciplinary team of various professionals, who need to understand also the business requirements, business strategies, and potential business opportunities. As such, this paper agrees the viewpoint of Polaine et al. [24] in which the service design may reflect on strategic level, not just on executional level.

\section{METHODOLOGY}

We conducted our research at Laurea University of Applied Sciences (Laurea) at the Laurea Leppävaara Campus, in Metropolitan area of Helsinki Finland. The Leppävaara Campus is dedicated in service innovation and design education. We explore how specific master's degree program students understand the competencies required in service business. Laurea approach in management education is to educate future multicompetent management professionals for expert and supervising positions. Learning is considered a way of creating new knowledge and new management competences that links learning to innovation activities in the relevant field. The aim of the education is to build a working life learning process that emphasizes expertise, creativity and goal orientation, developing problem solving, continuous learning and self-development.

At Laurea, we identified business practitioners studying service design at a master's degree program. The aim of the degree program is not to educate service designers, but future business professionals for managerial positions. The purpose of the master's degree program is to educate the leaders for organisations adopting both the service-driven perspective and service design approach. As such, the program includes some practical education on service design processes, methods and tools, but is focused on understanding the needs required in business management due to the change of the theoretical point of view. The content service design leadership education in Laurea consists of seven thematic aspects defined by literary review and evaluated together with working life experts: Service design thinking, service design methods and tools, service design process, strategic management, new business model development, co-creation, and management accounting. The degree program follows the frameworks of EQF and NQF.

We carried out the study which aimed at deepen the understanding of students' service design expectations. As this paper reports the preliminary results of the ongoing study, the research method is limited to the survey analysis only. The research data was gathered during the multidisciplinary 
Master's degree studies in service design in 2017. The case study research was selected because the study investigates a contemporary phenomenon within its life context and it uses multiple sources of evidence. This descriptive single case study uses a combination collected data (semi-structured survey), observation and content analysis to elaborate the expectations and actual competence development of master's students.

The degree is 90 ECTS credits with eligibility requirement of Bachelor's degree and a minimum of 3 years of working experience. The students have a wide variety in the backgrounds when entering into the degree program. These include: various bachelor level degrees (IT, business and administrative sciences); some may have already master's degree in other discipline; various working experiences in both timewise, careers or industries, and motivations to study master's degree. The aim of the study was to get better understanding of students' expectations, to get new insights, and to further develop the master's degree program.

The research data was collected during the study by a questionnaire consisting of multiple-choice and open-ended questions. The survey was created in Finnish language, i.e. the native language of the students. The analysis was executed in Finnish language also, and the findings translated to English (for the benefit of the reader). The media of the survey was in-house digital eform (eduixReports v1.0, build: 20081113), that allows the responses to be downloaded into excel for further analysis. The response time was not limited. The approximation of time spend on the survey is $30-40$ minutes. The students were instructed to respond the survey during their contact day in December 2017.

Students were asked to evaluate their own service design competence and grade their competence related to the thematic aspect of service design (grading scale: $0=$ no competence $-5=$ excellent competence; 1 - poor, 2 - satisfactory, 3 - good, 4 - commendable, 5 - excellent). Note that we did not use Likert-scales in this survey, but the actual grading the students would give to themselves; to self-assess their own competence.

The responses were unidentified, treated as anonymous responses, and the responses were analysed in using excel. The background information of the student respondents included prior degree, the program identification number, and executed study points (number of credits, ECTS). The Master's degree program is total of 90 ECTS (1.5 years), from which 60 ECTS are individual course work and 30 credits is the master thesis project and reporting. The questionnaire was answered by 40 Master's degree students in Service Design, of whom 31 had completed less than 60 ETCS (typically 3-4 courses) and 9 students had completed at least 60 ECTS credits.

\section{PRELIMINARY SURVEY FINDINGS}

The preliminary findings suggest that the managerial competence develops slowly during higher education and competence requirements are fulfilled only when the master thesis project is accomplished.

\subsection{Service design competences identified by the students}

The first analysis of the responses in open-end questions shows the multifaceted competences in the leading service design (see figure 1) identified by the students. This wordcloud was created to demonstrate how many issues are included in discussion of the key competences in service design. Likewise, the distinction of the sizes of the letters approximates the popularity of the topic; the bigger the letter the more it was found in the responses. 


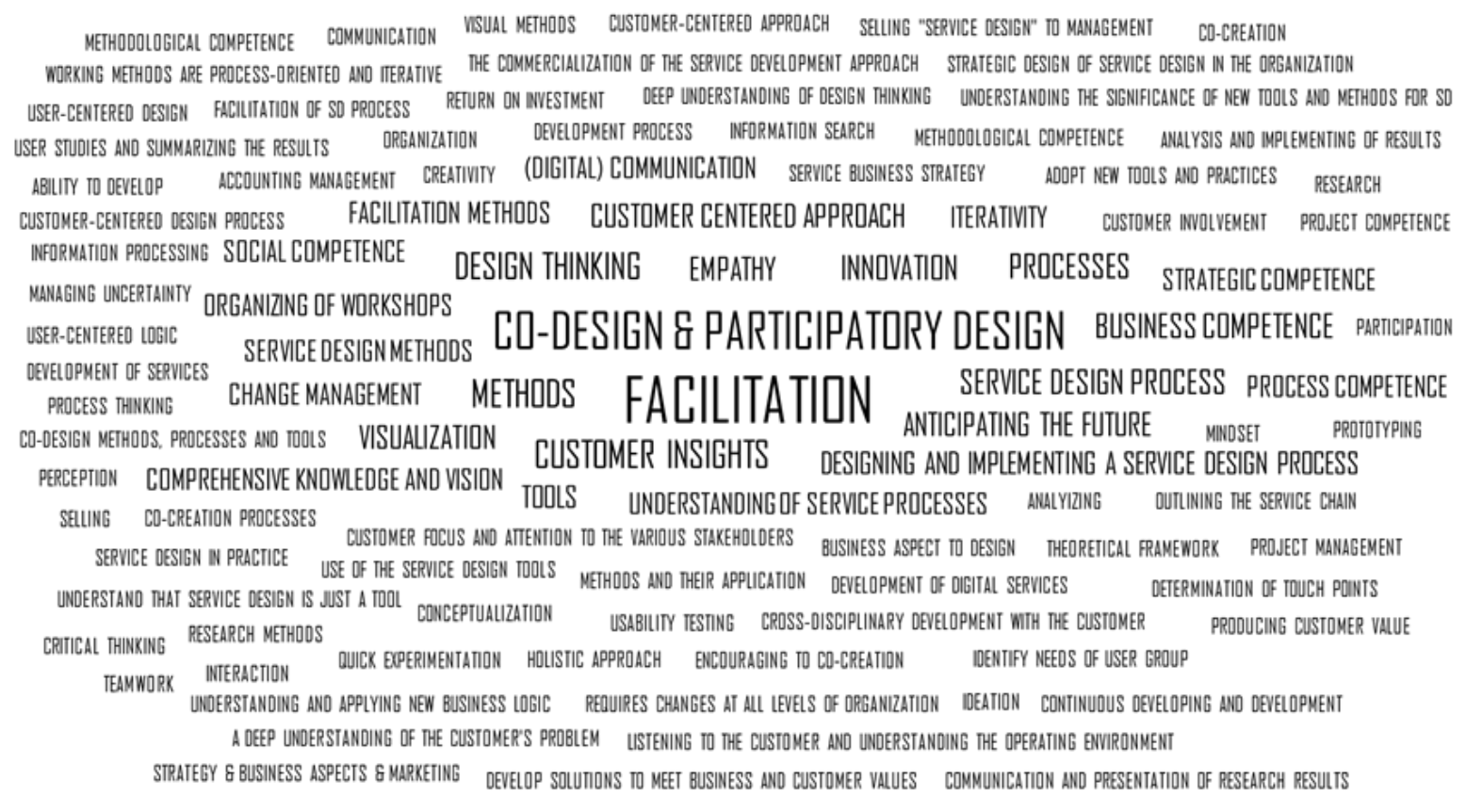

Figure1. Wordcloud of the key service design leadership competences identified by the students

The wordcloud demonstrates that the students do not distinguish between skills, capabilities and competences in general. Neither have they divided between theoretical frameworks i.e. service approach based competences from general management competences, or between operational skills and Meta skills. It seems that the students could not identify the central learning themes of the Master's degree program or interpret them as competences.

The wordcloud of expectations indicate that students seem to want only to complete the expertise on execution level rather than reaching the levels of development and strategy; needed in managerial positions.

\subsection{Comparing the students' responses}

The questionnaire was answered by 40 Master's degree students, of whom 31 had completed less than 60 ETCS (typically 3-4 courses) and 9 students had completed at least 60 ECTS credits. The student respondents were categorized according to the executed credits. In order to evaluate the progress of the competence development, the respondents group were divided in to groups $A$ and $B$. Respectively, Group A less than 60 ECTS acquired, and Group B at least 60 ECTS acquired.

To summarize the survey results, we can conclude that although the Group B respondents had only slightly more confident in their new competencies on average 1 grade better in comparison to the Group A. The biggest difference in competence evaluation was with the theme strategic management competence, in which in the Group A only $45 \%$ of the respondents were felt to have good (grade 3) competence to apply the strategic management in own organisation. In group B, the majority $(78 \%)$ of students estimated their competences as commendable (grade 4). Strategic management refers to the service thinking and application of the service logics as the main theoretical underpinning in business. This study shows that the long term competence development requires not only time, but various types of exercises during the education.

When respondents, group A were compared to respondents in group $B$, the average of the grades given differs approximate 1 grade - this shows that the long term competence development requires not only time, but various types of exercises during the education. Based on the analysis of the survey results a strong indication is that the business practitioners i.e. students do not have deep knowledge driven motivation for their studies. They need the examination certificate for potentially promoting the career. Secondly, they seem to want only to complement the expertise on execution level rather than reaching the levels of development and strategy; needed in managerial positions. A few students even 
go that far and state that theoretical knowledge is not needed in working life context, only practical use of the methods and tools. This clearly underlines the level of knowledge of those individual students, which will remain on the execution level jobs. And hardly understand the master's level education goals. The most essential finding is that the management competence develops very slowly and competence requirements are fulfilled only when the master thesis project is accomplished.

In the context of HEls, the assumption is that the prior education i.e. bachelor level and/ or master's education would include the Meta skills and the business management approach. The personal capabilities, working life capabilities and at least one conventional business capability should have been acquired with prior entering to the master's degree program and with the working life experiences. Based on the findings of this study, the prior degree studies hardly provide sufficient knowledge. Yet, the master's degree programs are developed under the assumption that the degree program could focus on the new competences such as service design leadership.

\section{CONCLUSIONS}

Leading the service design calls for the new management competences that need to intertwine service logics and service design. Leading service design, e.g. managing the service development in any organisations requires understanding the development and strategy level competencies. These stem for the theoretical underpinnings. The pure executional level expertise on carrying out service design projects is not comprehensive enough. Managers need wider knowledge on how the individual choices on service design tools, templates, methods and processes affect the business. To lead service design the manager needs to understand the business opportunities, the strategic vision of the firm, financial outcomes, to name a few.

The preliminary findings reveal significant trade-offs in planning and conducting the management education on master's level: The students represent working life and the findings indicate that despite the growing importance of services, the service thinking has not been considered the strategic choice in business. The service logic is not adopted as the guiding strategic principle leading the operational level execution. Thus the students, especially in the beginning of the degree program, perceive service design as end in itself rather than operationalization of service logics as it should be. During the independent thesis work, i.e. carrying out development work, the students internalize the service logics and their implications to development and innovation work. The role of service logic as the theoretical background in education needs to be reinforced, and strengthened in order to students to perceive the unity of service logics and service design. The HEls has a vital role in educating the management competences.

Global organizations and international foundations now include design on their agendas and this impacts in seen as a paradigm shift is taking place in the field of business and design. There seems to be a number of separate courses available providing a short-term solution to the challenge of a new professions. These aim at execution of service design practices. Thus, the knowledge and the acquired service design skills remain on superficial executional level. That is not, however, the role of master's degree education. The future managers lead service design and other activities for the benefit of the business, and work on development and strategy levels.

The role of HEls is pivotal in transforming the society and educating the future generations of professionals. Learning takes time, and the teaching practices, methods and pedagogical choices require renewal as the complexity increases. To ensure competent workforce in future, new education programs needs to be developed to meet the needs of the workforce, companies, and changing society. Higher education field transforms through education adults into managers and leaders of the society and business. The contribution of this paper is to advance new competences of service approach and leading service design.

As a conclusion, we suggest that the service design needs to be anchored to one of the conventional theoretical disciplines e.g. service marketing in order to enhance the academic reliability as an emerging discipline and to have impact in business management. Our study advances scholarly discussions of higher education and management competence development. The contribution of this paper is to advocate the new management competences and posit the emerging discipline of service design to management education. The findings reveal significant expectations for education across the master's students. Consistent with our expectations, both curriculum development and time span needs to be considered. The paper increases knowledge of the management education in modern world. The new insights for management education include competencies of leading the service 
design projects in organisations. This requires understanding of strategic approaches and related development methods: application of service design benefits from the service driven strategy. Likewise, design thinking needs to be understood. These approaches in and with business model development capabilities would benefit from service design process application with service design methods and tools, and co-creation procedures, only when the management accounting issues such as pricing, investment calculations and cost analyses are carried out.

As suggestions for further research, we detected several interesting issues during this study. First, the role of digitalization and technology advances in education service design leadership competencies. Second, the role of visualization in education in contrast to the written argumentation. Thirdly, the metrics related to service design productivity from the business management point of view. The different educational backgrounds of students will have an impact on learning and competence development, which requires further research. Thus, we envision more multidisciplinary service driven education programs in future.

\section{REFERENCES}

[1] T. Wallin Andreassen; P. Kristensson; L. Lervik-Olsen; A. Parasuraman; J. McColl-Kennedy.; B. Edvardsson \& M. Colurcio, "Linking service design to value creation and service research" Journal of Service Management, vol. 27, no.1, pp.: 21-29. 2016

[2] C. Grönroos, “Adopting a service logic for marketing”. Marketing Theory, vol. 6, no. 3, pp. 317-333, 2006

[3] R.F. Lusch \& S.L. Vargo, Service-Dominant Logic - premises, perspectives and possibilities. UK: Cambridge University Press, 2014

[4] C. Grönroos, C., "Service logic revisited: who creates value? And who co-creates?" European Business Review, No. 20, pp.298-314. 2008

[5] S. L. Vargo, "Customer Integration and Value Creation: Paradigmatic Traps and Perspectives". Journal of Service Research, No.11, pp. 211-215, 2008

[6] A. Meroni \& D. Sangiorgi, Design for services. Farnham, Surrey, UK: Gower Publishing. 2011

[7] C. Grönroos \& P. Voima, P. "Critical Service Logic: making sense of value creation and cocreation". Journal of the Academy of Marketing Science, no. 41, pp. 133-150, 2013

[8] P.P. Maglio; C.A. Kieliszewski \& J.C. Spohrer, James C. (Eds) Handbook of Service Science, New York USA: Springer, 2010

[9] A.F. Payne; K. Storbacka \& P. Frow, "Managing the co-creation of value", Journal of the Academy Marketing Science, no. 36, pp. 83-96, 2008

[10] K. Heinonen; T. Strandvik; K-J. Mickelsson; B. Edvardsson; E. Sundström \& P. Andersson, "A customer-dominant logic of service", Journal of Service Management, vol. 21, no. 4, pp. 531 - 548, 2010

[11] K. Heinonen; T. Strandvik \& P. Voima, "Customer dominant value formation in service", European Business Review, vol. 25, no.2, pp. 104-123, 2013

[12] S.L. Vargo \& R.F. Lusch, "Evolving to a New Dominant Logic for Marketing". Journal of Marketing, no. 68, pp. 1-17, 2004

[13] S. L. Vargo \& R. F. Lusch, "Service-dominant logic: continuing the evolution". Journal of the Academy of Marketing Science, no. 36, pp.1-10, 2008

[14] C. Grönroos \& A. Ravald, "Service as business logic: implications for value creation and marketing", Journal of Service Management, vol. 22, no. 1, pp. 5-22, 2011

[15] J. Ojasalo \& K. Ojasalo "Creating Competences in Service Innovation and Design. The SID Master's Programme for Practitioners Combines Business and Design Competences". Touchpoint - The Journal of Service Design, vol. 3, no. 3, January, pp. 58-61, 2012

[16] IfM, and IBM," Succeeding through service innovation: A service perspective for education, research, business and government". pp. 1-33; 2008 
[17] J. C., Spohrer; M. Gregory \& G. Ren, "The Cambridge-IBM SSME", white paper revisited, in Handbook of Service Science, service science: research and Innovations in the Service Economy. P. P. Maglio, C. A. Kieliszewski, and J. C. Spohrer, (eds.), Springer, pp. 677-706., 2010

[18] P. Géczy; N. Izumi \& K. Hasida, K. "Service Science, Quo Vadis?" International Journal of Service Science, Management, Engineering and Technology, vol. 1, no.1, pp. 1-16, 2010

[19] M. Ferruzca; P. J. Tossavainen \& V. Kaartti, "Educating the future generation of service innovators in emerging markets: a tale from the land of 100000 lakes". In What's ahead in service research? New perspectives for business and society. T. Russo-Spena and Cristina Mele (eds.) 26th Annual RESER Conference 2016, pp. 338-350, 2016

[20] M. Ferruzca; P. J. Tossavainen \& V. Kaartti, "Educating the future generations of service innovators: Insights from Finland". European Review of Service Economics and Management, vol. 2, no. 2, pp. 93-113, 2017

[21] S. Kurtmollaiev; A. Fjuk; P.E. Pedersen; S.; Clatworthy\& K. Kvale, "Organizational Transformation Through Service Design: The Institutional Logics Perspective". Journal of Service Research, vol. 21, no.1, pp.59-74, 2018

[22] S. Miettinen \& A. Valtonen, A. (Eds.). "Service design with theory: Discussions on change, value and methods". Rovaniemi, Finland: Lapland University Press, 2012

[23] I. Stigliani \& A-L. Fayard, A.-L. "Designing new customer experiences: A study of sociomaterial practices in service design". Discussion paper 2010/2. London, UK: Imperial College; 2010

[24] A. Polaine: L. Lovlie \& B. Reason, Ben "Service design. From insight to implementation". Brooklyn, NY, USA: Rosenfeld Media, 2013

[25] K. Wetter-Edman, "Designing for services. A framework for articulating designers' contribution as interpreter of users' experience". Doctoral Dissertation. Gothenburg, Sweden: University of Gothenburg, 2014

[26] M. Stickdorn \& J. Schneider, (eds.) "This is Service Design Thinking: basics - tools - cases". Amsterdam, NL: BIS Publishers, 2011

[27] S. Moritz, "Service Design, A practical access to an evolving field", Köln, Germany: KISD MEDes, 2005

[28] J. Liedtka \& T. Ogilvie "Designing for Growth: a design thinking tool kit for managers", New York, USA: Columbia University Press, 2011

[29] K. Tschimmel, K. "Design Thinking as an effective Toolkit for Innovation". In Proceedings of the XXIII ISPIM Conference: Action for Innovation: Innovating from Experience. Barcelona, Spain. 2012

[30] T. Mattelmäki, T. Design Probes. Doctoral Dissertation. Helsinki; Finland: University of Art and Design, 2006

[31] P. J. Tossavainen, "The service capabilities: Steps to service designed business." AMA ServSig International Research Conference, Hanken School of Economics, Helsinki, Finland, 2012 